\title{
EVALUATION OF NEW HOLLAND CR9080 OPERATION
}

\author{
Jerzy Bieniek ${ }^{*}$, Łukasz Żarek, Leszek Romański, Piotr Komarnicki, Przemysław Kobel
}

Institute of Agricultural Engineering, Wroclaw University of Environmental and Life Sciences

*Corresponding author: e-mail: jerzy.bieniek@up.wroc.pl

\begin{tabular}{|c|c|}
\hline ARTICLE INFO & ABSTRACT \\
\hline $\begin{array}{l}\text { Article history: } \\
\text { Received: January } 2017 \\
\text { Received in the revised form: } \\
\text { January } 2017 \\
\text { Accepted: February } 2017\end{array}$ & \multirow{2}{*}{$\begin{array}{l}\text { The paper evaluates operation of the separation unit of NH CR9080 } \\
\text { combine harvester. A considerable technical and technological progress } \\
\text { has taken place in presently used harvesters. Among others, efficiency } \\
\text { increased and equipment has been enhanced with elements which } \\
\text { improve the operation quality. The objective of the paper was to deter- } \\
\text { mine the quality of the separating unit of a combine harvester New } \\
\text { Holland CR9080. During the research, losses on screens and rotor, } \\
\text { cutting height of rapeseed, mowing speed, rotation of fans, rotors and } \\
\text { engine were determined. Relation of losses on screens to combine } \\
\text { operation parameters was determined with a model of multiple regres- } \\
\text { sions. The rotational speed of rotors, mowing speed and rotational } \\
\text { speed of the combine engine have a significant effect on losses on } \\
\text { screens at the rapeseed harvesting with the investigated combine. }\end{array}$} \\
\hline $\begin{array}{l}\text { Key words: } \\
\text { combine harvester, } \\
\text { separator, } \\
\text { rapeseed losses }\end{array}$ & \\
\hline
\end{tabular}

\section{Introduction and objective of the paper}

An economic development degree of the country depends inter alia on the level of grain production. The last period shapes Poland as a stable grain producer. The sowing area in Poland in 2008 was 8.6 million, from which almost 27 million tons of grain was harvested. In 2014, the sowing area increased and it was 10.3 million of ha. The average crop of grain in the country' scale was 3.8 tons form one hectare (Karpiński, 2015). In the world, the area sown with grains in 2014 was 712 million ha out of which 2.5 billion tons of grains were obtained; in Europe 60.5 million hectare which gave the crop in the amount of 315 million tons of grains. Such a vast sowing area causes a demand for more efficient combine harvesters (Bieniek, 2011; Dreszer et al., 2008; Miłosz, 2000; Wecker, Kutzbach et al., 1996; www1).

Presently, combine harvesters are produced by such companies as: Claas, John Deere, New Holland, Case HI, Fendt, which are universal machines which constitute a basis of a machinery park during harvesting. Due to many replaceable adapters, working elements and possibility of selection of relevant working parameters, these machines may be used for harvesting of various plant species. Each company creates technical solutions which they apply in their models (Bieniek, 2003 and 2011; RPT, 2012; Molendowski et al., 2011).

The quality of operation of the harvester may be determined with many parameters but the most important is purity and grain losses. Capacity is the next parameter taken into 
consideration at the evaluation of the combine harvester, which should be strictly related to standards concerning losses and grain purity (Bieniek, 2010; Beck, 2000; Komarnicki et al., 2007).

A classic combine harvester as a universal machine may be adjusted also to harvesting of corn and soya (Przybył and Sęk, 2010). The next stage in adjusting the machine for harvesting of a particular crop was the change of the harvesting device and mounting relevant working elements of the combine such as: elongation of a table and equipping it with vertical side scythes designed for harvesting of rapeseed (Żak et al., 2007).

Combine harvesters produced in recent years are advanced machines with regard to mechatronics. Operation parameters of harvesters are controlled by means of sensors and proceeded by an on-board computer which automatically selects working settings, optimally to existing field conditions (Baruah, Panesar, 2005a, 2005b; Nik et al., 2009; Tanaś, Zagajski, 2008). Due to the use of automatic control system of working units, harvesters became more efficient. For example, moisture sensors, which were used in harvesters cause decrease of damage and grain losses in the harvesting process (Liu, Leonard, 1993; Miu, Kutzbachb, 2008a, 2008b; Tanaś et al., 2008;Tanaś, Zagajski, 2010; Molendowski et al., 2012).

The objective of the paper was to analyse the impact of the selected new technical solutions used in the separating unit of New Holland CR9080 combine harvester on the quality of operation. The quality of operation of the separation unit was evaluated through analysis of rapeseed losses on screens and rotors.

\section{Object and methodology of research}

The research was carried out on a field near Gródno town in Dolnośląskie Voivodeship.

Agrotechnical conditions during the test were as follows:

- 54 ha field with varied land slope from $0^{\circ}$ to $6^{\circ}$,

- harvesting of seeds - rapeseed,

- average height of plants is $1.6 \mathrm{~m}$,

- moisture of seeds at $10^{35}$ was $9.8 \%$,

- moisture of seeds at $14^{20}$ was $9.2 \%$.

Four test fields were set on the area. Five iterations were made on each field. Performance of the harvester, its demand for energy, quality of work: losses, damage and purity of seeds were parameters taken into consideration during evaluation of the quality of harvesters operation (Anil et al., 1998; Bieniek, 2010; Maertens et al., 2001; Molendowski et al., 2012). During harvesting the following parameters were measured:

- losses on screens $s_{s},(\%)$

- losses on rotors $s_{r},(\%)$

- cutting height of rapeseed $h,(\mathrm{~cm})$

- harvester speed $V,\left(\mathrm{~km}^{\circ} \mathrm{h}^{-1}\right)$

- fan rotations $n_{w},\left(1 \cdot \mathrm{min}^{-1}\right)$

- rotors rotations $n_{r},\left(1 \cdot \mathrm{min}^{-1}\right)$

- engine rotations $n_{s},\left(1 \cdot \mathrm{min}^{-1}\right)$ 
The average crop from entire field was $3.65 \mathrm{t} \cdot \mathrm{ha}^{-1}$. Each sample of harvested rapeseed from the investigated field was weighted on the Metal-Tech loading cart (Fig. 1) equipped with electronic scales. Moisture of seeds was determined with a moisture meter Unimeter Super Digital

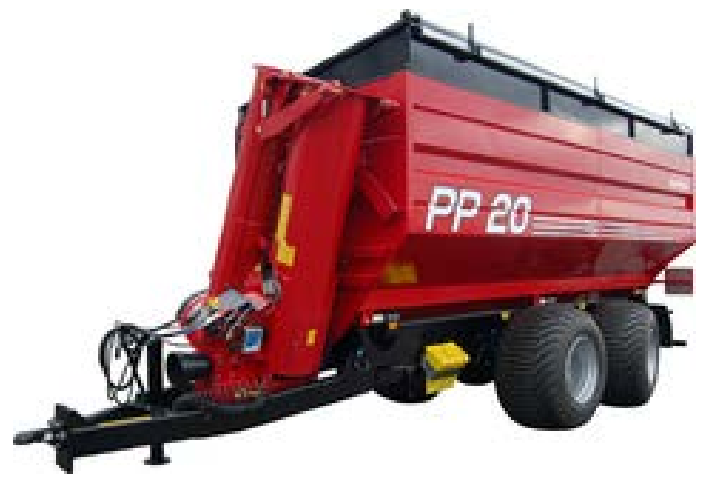

Figure 1. Loading cart by Metal-Tech (www2)

The object of the research consisted of a separation unit of New Holland CR9080 harvester. The unit with the presented system of screens (Fig. 2) consisted of: grain table 1, initial screen, 3, top screen 4 and bottom screen 5, where a working slot was set during research - upper screen equal to $9 \mathrm{~mm}$ and bottom screen $2 \mathrm{~mm}$.

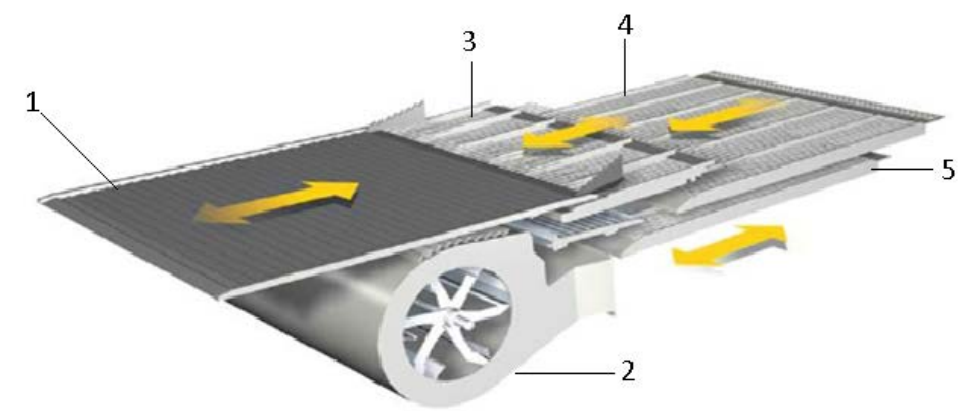

Figure 2. The system of screens in CR9080 (www3): 1 - grain table, 2 - fan, 3 - initial screen, 4 - top screen, 5 - bottom screen

The surface of screens under the influence of air stream generated by the axial 6-blade fan was $6.5 \mathrm{~m}^{2}$ and ensured a uniform air flow on the entire length of the working length of a screen. Screens which maintain separation process balance of the harvested mass were used in the harvester. Screens were controlled with electric engines from the operator's cab. An acoustic sensor presented in figure 3 calculated losses of rapeseed, generated within a chaff riddle screen box. 


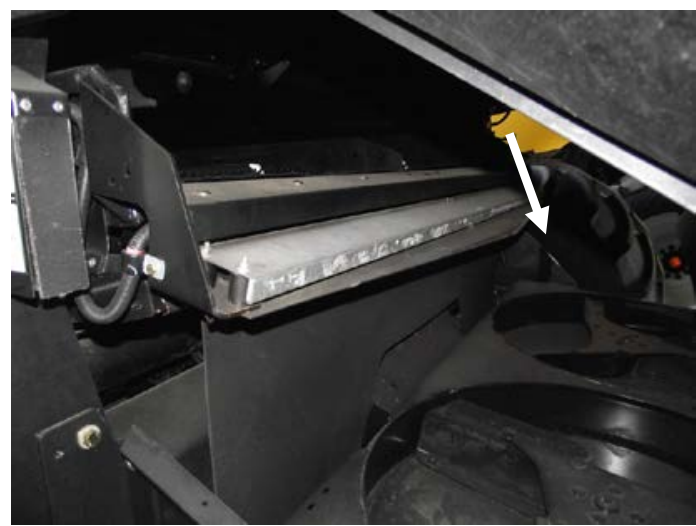

Figure 3. Sensor of losses on screens in New Holland CR 9080 (photo by author)

Underthreshed material falling from the screen was carried out to side threshers and threshed seeds were transported to an overseeder. The sensor of undershred material mounted on a conveyor informed on its amount which allowed optimal setting of operation parameters of machines (www2). The rotational speed of a fan during driving down or up of a slope was regulated and automatically set by the installed Opti Fan system. Principles of operation of the system were presented in figure 4 (www3).

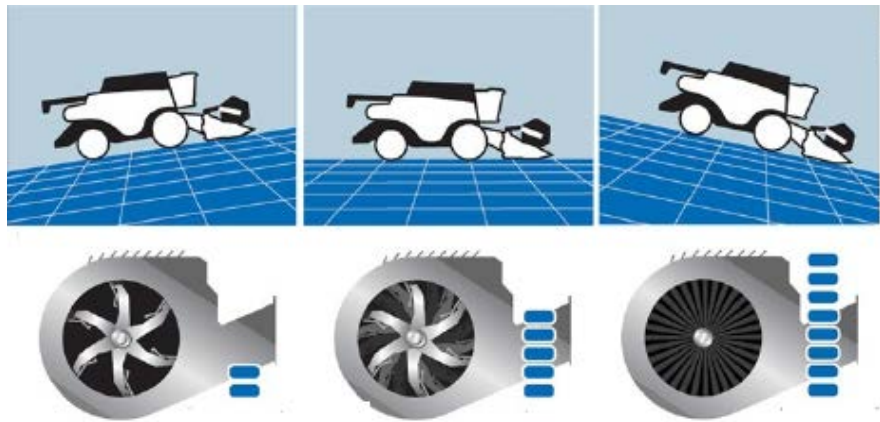

Figure 4. Opti Fan system in combine harvester CR9080 (www3)

\section{Research results}

Table 1 sets the results of statistical calculations of the measured parameters which describe the harvester operation at rapeseed threshing on four experimental fields and the measurement values from the tests which were carried out.

Experimental fields differed with acreage (1.5-1.93 ha) and thus differed with the number of measurements (121-215) and the size of the harvested crop (5.96-7.1 ton). The harvesting time was different on each experimental field caused by agri-technical factors such as: lay of the fields, density of plants on particular fields and conditions of harvester's operation. 
Evaluation of New Holland...

Table 1.

Results of statistical calculations of the investigated parameters of the harvester operation and measurement values

\begin{tabular}{|c|c|c|c|c|c|}
\hline \multirow{2}{*}{ Parameter } & \multicolumn{4}{|c|}{ Field number } & \multirow{2}{*}{ Test result } \\
\hline & 1 & 2 & 3 & 4 & \\
\hline Acreage (ha) & 1.50 & 1.93 & 1.73 & 1.60 & \\
\hline Threshing time (minutes) & 33 & 23 & 28 & 27 & \\
\hline Mass (tonne) & 5.96 & 7.1 & 6.58 & 6.8 & \\
\hline Number of results $N$ & 215 & 126 & 147 & 121 & \\
\hline \multicolumn{6}{|l|}{ Losses on screens $S_{S}(\%)$} \\
\hline$M \pm S D$ & $3.26 \pm 2.06$ & $3.42 \pm 1.34$ & $3.86 \pm 1.75$ & $3.22 \pm 1.23$ & \multirow{4}{*}{$p<0.001$} \\
\hline$M e$ & 2.50 & 3.70 & 3.70 & 2.80 & \\
\hline$\left(Q_{1} ; Q_{3}\right)$ & $(1.80 ; 5.60)$ & $(2.80 ; 3.70)$ & $(2.80 ; 5.70)$ & $(2.40 ; 3.70)$ & \\
\hline Min-Max & $0.23-7.93$ & $0.98-8.20$ & $0.80-8.60$ & $1.80-8.20$ & \\
\hline \multicolumn{6}{|l|}{ Losses on rotors $s_{r}(\%)$} \\
\hline$M \pm S D$ & $0.05 \pm 0.11$ & $0.02 \pm 0.00$ & $0.02 \pm 0.00$ & $0.02 \pm 0.00$ & \multirow{4}{*}{$p<0.001$} \\
\hline$M e$ & 0.02 & 0.02 & 0.02 & 0.02 & \\
\hline$\left(Q_{1} ; Q_{3}\right)$ & $(0.02 ; 0.02)$ & $(0.02 ; 0.02)$ & $(0.02 ; 0.02)$ & $(0.02 ; 0.02)$ & \\
\hline Min-Max & $0.02-0.75$ & $0.02-0.02$ & $0.02-0.02$ & $0.02-0.02$ & \\
\hline \multicolumn{6}{|l|}{$\begin{array}{l}\text { Rotational speed of engine } \\
n_{s}\left(\min ^{-1}\right)\end{array}$} \\
\hline$M \pm S D$ & $2099 \pm 8$ & $2100 \pm 5$ & $2095 \pm 18$ & $2099 \pm 5$ & \multirow{4}{*}{$p<0.001$} \\
\hline$M e$ & 2100 & 2100 & 2100 & 2100 & \\
\hline$\left(Q_{1} ; Q_{3}\right)$ & $(2100 ; 2100)$ & $(2100 ; 2100)$ & $(2090 ; 2100)$ & $(2100 ; 2100)$ & \\
\hline Min-Max & $2000-2110$ & $2090-2150$ & $2000-2120$ & $2090-2110$ & \\
\hline \multicolumn{6}{|l|}{$\begin{array}{l}\text { Rotational speed of rotors } \\
n_{r}\left(\min ^{-1}\right)\end{array}$} \\
\hline$M \pm S D$ & $581 \pm 6$ & $580 \pm 1$ & $578 \pm 6$ & $579 \pm 3$ & \multirow{4}{*}{$p=0.001$} \\
\hline$M e$ & 580 & 580 & 580 & 580 & \\
\hline$\left(Q_{1} ; Q_{3}\right)$ & $(580 ; 580)$ & $(580 ; 580)$ & $(570 ; 580)$ & $(580 ; 580)$ & \\
\hline Min - Max & $570-590$ & $570-580$ & $560-590$ & $560-580$ & \\
\hline \multicolumn{6}{|l|}{$\begin{array}{l}\text { Rotational speed of fans } n_{w} \\
\left(\min ^{-1}\right)\end{array}$} \\
\hline$M \pm S D$ & $600 \pm 7$ & $600 \pm 0$ & $597 \pm 11$ & $600 \pm 3$ & \multirow{4}{*}{$p=0.007$} \\
\hline Me & 600 & 600 & 600 & 600 & \\
\hline$\left(Q_{1} ; Q_{3}\right)$ & $(600 ; 600)$ & $(600 ; 600)$ & $(600 ; 600)$ & $(600 ; 600)$ & \\
\hline Min - Max & $570-660$ & $600-600$ & $550-620$ & $580-610$ & \\
\hline \multicolumn{6}{|l|}{$\begin{array}{l}\text { Cutting height of a field } h \\
\text { (cm) }\end{array}$} \\
\hline$M \pm S D$ & $19.0 \pm 9.7$ & $23.4 \pm 10.1$ & $21.9 \pm 13.2$ & $17.5 \pm 10.2$ & \multirow[t]{3}{*}{$p<0.001$} \\
\hline$M e\left(Q_{1} ; Q_{3}\right)$ & $18(15 ; 22)$ & $22(19 ; 25)$ & $20(16 ; 22)$ & $16(14 ; 18)$ & \\
\hline Min-Max & $1-82$ & $4-86$ & $7-86$ & $1-85$ & \\
\hline \multicolumn{6}{|l|}{ Driving speed $V\left(\mathrm{~km} \cdot \mathrm{h}^{-1}\right)$} \\
\hline$M \pm S D$ & $4.4 \pm 0.7$ & $4.7 \pm 0.9$ & $4.4 \pm 1.3$ & $4.2 \pm 0.7$ & \multirow{3}{*}{$p<0.001$} \\
\hline $\operatorname{Me}\left(Q_{1} ; Q_{3}\right)$ & $5(4 ; 5)$ & $5(5 ; 5)$ & $4(4 ; 5)$ & $4(4 ; 4)$ & \\
\hline $\operatorname{Min}-\operatorname{Max}$ & $1-7$ & $0-7$ & $0-11$ & $1-8$ & \\
\hline
\end{tabular}


The average losses of seeds on screens were within 3.36\% to 3.86\% depending on the investigated field. The minimum and maximum values of this parameter result from a description of combine harvester operation. Losses on screens are parameters which define the quality of operation of a harvester; the minimum losses were $0.23 \%$ and the maximum were $8.6 \%$. Losses on rotors are small since they do not exceed 1\%. The rotational speed of an engine in assumptions of the harvester operation was $2100 \mathrm{~min}^{-1}$ and the average from measurements of this parameter on all investigated fields was the same. The engine operation at these rotations optimizes the remaining parameters of the harvester such as rotations of rotors and movement of screens in the box of a chaff riddle screen. They influence also the fuel consumption. The change of the parameter of the rotational speed of the engine on particular fields during research resulted from the variable cycle of machine operation and was within 2000- $2150 \mathrm{~min}^{-1}$. The rotational speed of rotors was the following parameter determined during research. In the initial settings of the machine, it was $580 \mathrm{~min}^{-1}$ and the average from measurements on each particular field was the same. Deviations from the set speed resulted from the variable loading of the threshing unit and were within 560-590 min ${ }^{1}$. When the excessive amount of mass got to the threshing section, the rotational speed of rotors was decreasing. The drive computer registered the decrease of the rotational speed of rotors and increased them by the increase of the rotational speed of the engine to prevent blocking in the threshing unit. After a greater amount of mass was threshed, the rotational speed of rotors returned to its set value. The height of cutting a field was the most variable parameter on all fields. Its variability results from the lay of the field terrain. Auto-tracing of the area by a header changes the cutting height of a field independently from the operator. Variability of the cutting height results also from characteristics of combine harvester operation on headlands. The cutting height of a field was from 01 to $86 \mathrm{~cm}$. The driving speed of a combine harvester is the next parameter which may be monitored during research. The average speed of the combine during threshing was within 4.2-4.7 $\mathrm{km} \cdot \mathrm{h}^{-1}$ and the maximum was $11 \mathrm{~km} \cdot \mathrm{h}^{-1}$. The change of the driving speed during harvesting results from a variable lay of the surface of fields and the nature of machine operation namely returns and technological crossings.

Figure 5 presents results of statistical calculations of losses on screen including particular experimental fields. On each of the investigated fields, the differences between the border values of the investigated parameter were considerable. The smallest differences were reported on fields no. 2 and 4 . The biggest differences were reported on field 1 . Table 2 presents results of multiple comparisons of losses on screens with a post-hoc test between particular fields. Losses on screens on field no. 1 were significantly smaller than on fields 2 and $3(2.5 \%$ and $3.7 \%$; $\mathrm{p}<0.05)$.

Results of multiple comparisons of engine rotations $n_{s}$ with a post-hoc test during combine harvester operation on fields are presented in table 3 . The rotational speeds of the engine on all investigated fields were similar and were respectively $2099 \mathrm{~min}^{-1}, 2100 \mathrm{~min}^{-1}$, $2095 \mathrm{~min}^{-1}$ and $2099 \mathrm{~min}^{-1}$. 


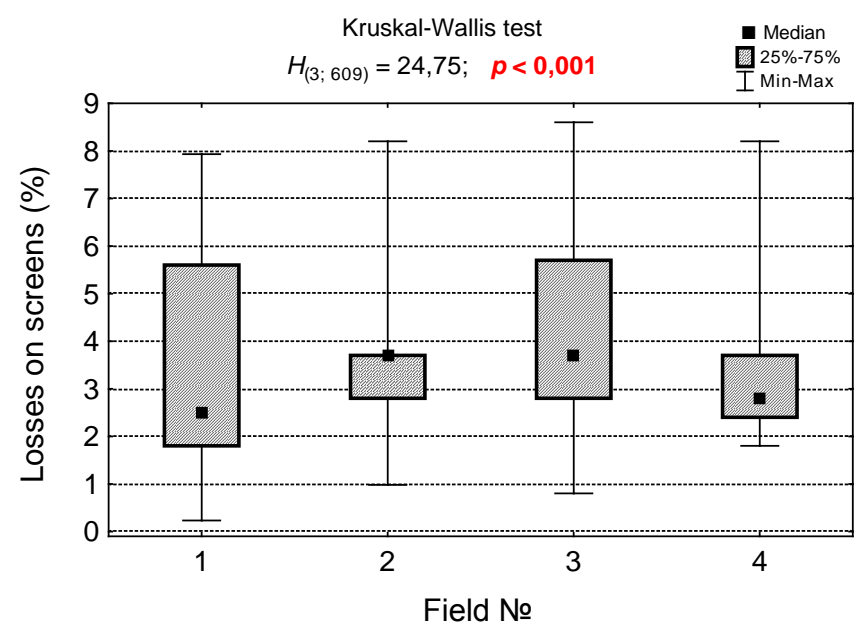

Figure 5. Comparison of losses on screens $s_{s}$ on four fields and results of Kruskal-Wallis test

Table 2.

Results of multiple comparisons of losses on screens $s_{s}$ with a post-hoc test

\begin{tabular}{lcccc}
\hline & Field 1 & Field 2 & Field 3 & Field 4 \\
& $s_{s}=2.5(\%)$ & $s_{s}=3.7(\%)$ & $s_{s}=3.7(\%)$ & $s_{s}=2.8(\%)$ \\
\hline P1 & $\times$ & $\boldsymbol{p}=\mathbf{0 . 0 2 4}$ & $\boldsymbol{p}<\mathbf{0 . 0 0 1}$ & $p=0.324$ \\
P2 & $\boldsymbol{p}=\mathbf{0 . 0 2 4}$ & $\times$ & $p=0.691$ & $p=1.000$ \\
P3 & $\boldsymbol{p}<\mathbf{0 . 0 0 1}$ & $p=0.691$ & $\times$ & $p=0.098$ \\
P4 & $p=0.324$ & $p=1.000$ & $p=0.098$ & $\times$ \\
\hline \multicolumn{2}{l}{ Significant difference were marked at the level of $p<0.05$} & &
\end{tabular}

Table 3.

Results of multiple comparisons of engine rotations $n_{s}$ with a post-hoc test

\begin{tabular}{ccccc}
\hline & Field 1 & Field 2 & Field 3 & Field 4 \\
& $n_{s}=2099\left(\mathrm{~min}^{-1}\right)$ & $n_{s}=2100\left(\mathrm{~min}^{-1}\right)$ & $n_{s}=2095\left(\mathrm{~min}^{-1}\right)$ & $n_{s}=2099\left(\mathrm{~min}^{-1}\right)$ \\
\hline P1 & $\times$ & $p=0.610$ & $\boldsymbol{p}=\mathbf{0 . 0 1 7}$ & $p=0.976$ \\
P2 & $p=0.610$ & $\times$ & $\boldsymbol{p}<\mathbf{0 . 0 0 1}$ & $p=0.860$ \\
P3 & $\boldsymbol{p}=\mathbf{0 . 0 1 7}$ & $\boldsymbol{p}<\mathbf{0 . 0 0 1}$ & $\times$ & $\boldsymbol{p}=\mathbf{0 . 0 1 1}$ \\
P4 & $p=0.976$ & $p=0.860$ & $\boldsymbol{p}=\mathbf{0 . 0 1 1}$ & $\times$ \\
\hline
\end{tabular}

Significant difference were marked at the level of $p<0.05$

Table 4 presents results of multiple comparisons of the rotational speeds of rotors $n_{s}$ with a post-hoc test during combine harvester operation on fields. The rotational speeds of rotors were insignificant between harvesting on fields 1 and 3 and 4 and between fields 2 and 3. 
Table 4

Results of multiple comparisons of rotors rotations $n_{\mathrm{r}}$ with a $\mathrm{n}_{\mathrm{r}}$ test

\begin{tabular}{ccccc}
\hline & Field 1 & Field 2 & Field 3 & Field 4 \\
& $n_{r}=580.6\left(\mathrm{~min}^{-1}\right)$ & $n_{r}=579.9\left(\mathrm{~min}^{-1}\right)$ & $n_{r}=577.8\left(\mathrm{~min}^{-1}\right)$ & $n_{r}=578.8\left(\mathrm{~min}^{-1}\right)$ \\
\hline P1 & $\times$ & $p=0,748$ & $\boldsymbol{p}<\mathbf{0 . 0 0 1}$ & $\boldsymbol{p}=\mathbf{0 . 0 4 1}$ \\
P2 & $p=0.748$ & $\times$ & $\boldsymbol{p}=\mathbf{0 . 0 0 4}$ & $p=0.345$ \\
P3 & $\boldsymbol{p}<\mathbf{0 . 0 0 1}$ & $\boldsymbol{p}=\mathbf{0 . 0 0 4}$ & $\times$ & $p=0.337$ \\
P4 & $\boldsymbol{p}=\mathbf{0 . 0 4 1}$ & $p=0.345$ & $p=0.337$ & $\times$ \\
\hline
\end{tabular}

Significant difference were marked at the level of $p<0.05$

The rotational speed of a fan $n_{w}$ on four investigated fields was presented in figure 6 . The most uniform readouts of the rotational speed of a fan, were reported during harvester operation on the field no. 2. The highest difference between the minimal and the maximum value was on the filed no. 3. Table 5 presents results of the post-hoc test on the rotational speed of the fan.

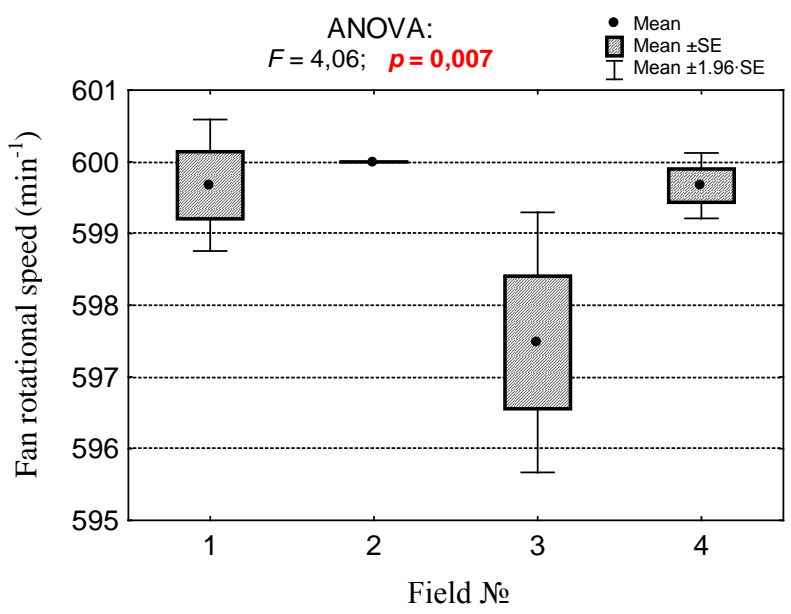

Figure 6. Comparison of fan rotational speed $n_{w}$ of harvester working on four fields and the results of analysis of variance

Table 5.

Results of multiple comparisons of fan rotations $\mathrm{n}_{\mathrm{w}}$ post-hoc test

\begin{tabular}{ccccc}
\hline & Field 1 & Field 2 & Field 3 & Field 4 \\
& $n_{w}=599.7\left(\mathrm{~min}^{-1}\right)$ & $n_{w}=600.0\left(\mathrm{~min}^{-1}\right)$ & $n_{w}=597.5\left(\mathrm{~min}^{-1}\right)$ & $n_{w}=599.7\left(\mathrm{~min}^{-1}\right)$ \\
\hline P1 & $\times$ & $p=0.982$ & $\boldsymbol{p}=\mathbf{0 . 0 3 5}$ & $p=1.000$ \\
P2 & $p=0.982$ & $\times$ & $\boldsymbol{p}=\mathbf{0 . 0 2 1}$ & $p=0.983$ \\
P3 & $\boldsymbol{p}=\mathbf{0 . 0 3 5}$ & $\boldsymbol{p}=\mathbf{0 . 0 2 1}$ & $\times$ & $p=0.069$ \\
P4 & $p=1.000$ & $p=0.983$ & $p=0.069$ & $\times$ \\
\hline
\end{tabular}

Significant difference were marked at the level of $p<0.05$

Table 6 presents results of multiple comparisons of cutting height of a field $h$ with a post-hoc test. 
Evaluation of New Holland...

Table 6.

Results of multiple comparisons of cutting height of a field h with a post-hoc test

\begin{tabular}{lcccc}
\hline & Field 1 & Field 2 & Field 3 & Field 4 \\
& $h=19.0(\mathrm{~cm})$ & $h=23.4(\mathrm{~cm})$ & $h=21.9(\mathrm{~cm})$ & $h=17.5(\mathrm{~cm})$ \\
\hline P1 & $\times$ & $\boldsymbol{p}=\mathbf{0 . 0 0 8}$ & $p=0.114$ & $p=0.678$ \\
P2 & $\boldsymbol{p}=\mathbf{0 . 0 0 8}$ & $\times$ & $p=0.686$ & $\boldsymbol{p}<\mathbf{0 . 0 0 1}$ \\
P3 & $p=0.114$ & $p=0.686$ & $\times$ & $\boldsymbol{p}=\mathbf{0 . 0 0 9}$ \\
P4 & $p=0.678$ & $\boldsymbol{p}<\mathbf{0 . 0 0 1}$ & $\boldsymbol{p}=\mathbf{0 . 0 0 9}$ & $\times$ \\
\hline Significant difference were marked at the level of $p<0.05$ & &
\end{tabular}

Significant difference were marked at the level of $p<0.05$

On field no. 2 the average height of cutting a field $h$ was the highest $23.4 \mathrm{~cm}$ in comparison to the field no. $417.5 \mathrm{~cm} ; \mathrm{p}<0.001$ and field no. $1119.0 \mathrm{~cm} ; \mathrm{p}=0.008$ and field no. 3 $21.9 \mathrm{~cm} ; \mathrm{p}=0.009)$.

\section{Univariate analysis of variance}

Because losses on screens $s_{s}$ on three fields differed significantly (table 1) for the purpose of analysis of regression they were given the following ranks: field 1 - rank 2, field 2 - rank 3, field 3 - rank 4 and field 4 - rank 1 . Figure 7 illustrates losses on screens $s_{s}$ for particular fields.

Table 7 presents values of linear regression coefficients of losses on screens with the analysed parameters (on all four fields together).

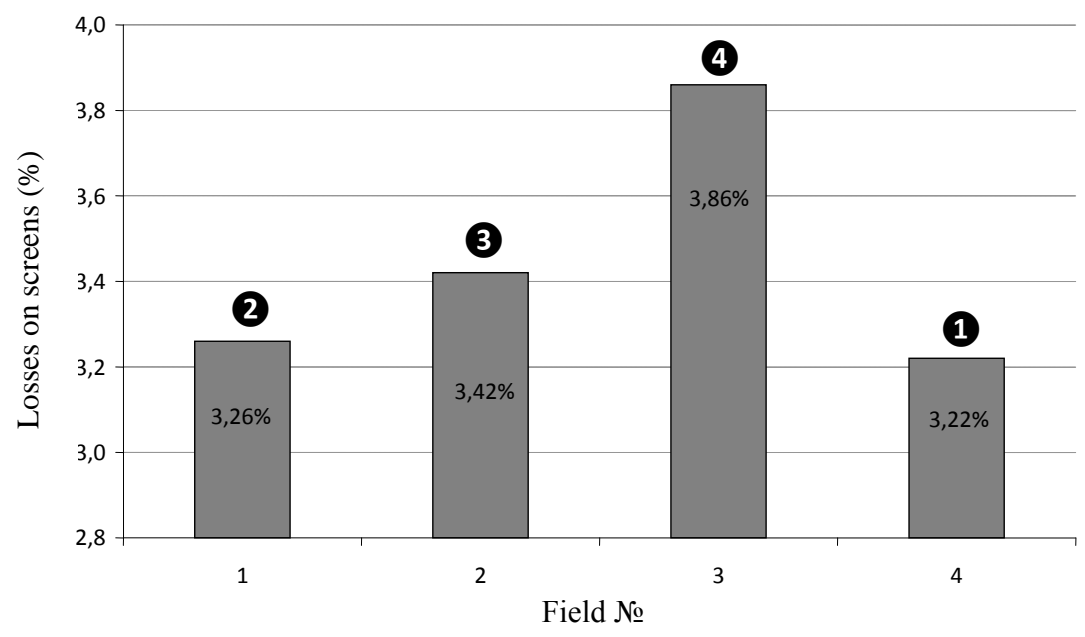

Figure 7. Losses on screens $s_{s}$ on four fields and their ranks 
J. Bieniek, Ł. Żarek, L. Romański, P. Komarnicki, P. Kobel

Table 7.

Coefficient of Pearson correlation of the analyzed parameters of losses on screens and their significance

\begin{tabular}{lcc}
\hline Parameter & $\begin{array}{c}\text { Pearson's } \\
\text { coefficient } \\
\text { of correlation }\end{array}$ & $\begin{array}{c}\text { Test } \\
\text { probability }\end{array}$ \\
\hline Rotational speed of an engine $\left(\mathrm{min}^{-1}\right)$ & $r=-0.136$ & $p=0.001$ \\
Rotational speed of rotors $\left(\mathrm{min}^{-1}\right)$ & $r=-0.309$ & $p<0.001$ \\
Rotational speed of a fan $\left(\mathrm{min}^{-1}\right)$ & $r=+0.043$ & $p=0.292$ \\
Cutting height of field $(\mathrm{cm})$ & $r=+0.141$ & $p<0.001$ \\
Driving speed $\left(\mathrm{km} \cdot \mathrm{h}^{-1}\right)$ & $r=+0.220$ & $p<0.001$ \\
Field rank & $r=+0.136$ & $p=0.001$ \\
\hline
\end{tabular}

Analysis do not include the rotational speed of fans because for $p>0.05$ it does not correlates significantly with losses of seeds on screens.

Multivariate analysis of variance includes the following parameters significantly influencing the losses on screens ( $Y$ - dependent variable, explained):

$X_{1}$ - engine rotations,

$X_{2}$ - rotors rotations,

$X_{3}$ - cutting height of field,

$X_{4}-$ driving speed,

$X_{5}$ - field rank,

$\varepsilon$ - corrective coefficient.

The following model was assumed:

$$
\mathrm{Y}=\mathrm{b}_{0}+\mathrm{b}_{1} \times \mathrm{X}_{1}+\mathrm{b}_{2} \times \mathrm{X}_{2}+\mathrm{b}_{3} \times \mathrm{X}_{3}+\mathrm{b}_{4} \times \mathrm{X}_{4}+\mathrm{b}_{5} \times \mathrm{X}_{5}+\varepsilon
$$

in which the values of coefficients $b_{0}, b_{1}, b_{2}, b_{3}, b_{4}$ and $b_{5}$ were estimated with a multiple regression method with the use of a backward stepwise technique The results of analysis were presented in table 8 . Where $\beta$ stands for the corrective coefficient, $\mathrm{SE}_{\beta}$ stands for the standard error of the corrective coefficient, letter b stands for the coefficient in the model, $\mathrm{SE}_{\mathrm{b}}$ stands for the standard error of the model coefficient, $p$ stands for statistical probability (Górniak, Wachnicki, 2004).

Table 8.

Results of multiple regression

\begin{tabular}{llllll}
\hline Independent variables & $\beta$ & $\mathrm{SE} \beta$ & $\mathrm{b}$ & $\mathrm{SE}_{\mathrm{b}}$ & $p$ \\
\hline Abscissa $\left(b_{0}\right)$ & & & 59.49 & 7.33 & $<\mathbf{0 . 0 0 0 1}$ \\
Engine rotations $\left(b_{1}\right)$ & -0.086 & 0.086 & -0.014 & 0.0061 & $\mathbf{0 . 0 2 3 1}$ \\
Rotors rotations $\left(b_{2}\right)$ & -0.299 & 0.038 & -0.0997 & 0.0126 & $<\mathbf{0 . 0 0 0 1}$ \\
Cutting height of field $\left(b_{3}\right)$ & +0.048 & 0.042 & 0.008 & 0.007 & 0.2556 \\
Driving speed $\left(b_{4}\right)$ & +0.205 & 0.038 & 0.386 & 0.071 & $<\mathbf{0 . 0 0 0 1}$ \\
Field rank $\left(b_{5}\right)$ & +0.067 & 0.038 & 0.109 & 0.062 & 0.0815 \\
\hline
\end{tabular}


Evaluation of New Holland...

Value of the coefficient of determination $\mathrm{R}^{2}=0.153$ informs that only $15.3 \%$ on the variability of losses on screens are influenced by rotations of rotors and engine and the driving speed which is presented by the following model:

$$
S_{S}=59.49-\left(0.1 \times n_{r}\right)+(0.39 \times V)-\left(0.014 \times n_{s}\right)
$$

Losses on screens in a harvester are affected the most by rotational speeds of rotors $n_{r}(\beta=-0.299)$, then the driving speed $V(\beta=0.205)$ and the least by rotations of an engine $n_{s}(\beta=-0.086)$. Parameters of the cutting heights of a field $h$ and the field rank were not included in the model $(p>0.05)$.

\section{Conclusions}

1. Parameters of combine harvester operation on each of 4 investigated fields differed significantly between each other. The average values of losses on screens were within $3.22 \%$ to $3.96 \%$. On the other hand, losses on rotors were from $0.02 \%$ to $0.05 \%$.

2. The rotational speed of a fan was changing during operation of the combine harvester within 550-600 $\mathrm{min}^{-1}$. These changes were caused by Opti Fan system operation which automatically controlled the rotational speed of a fan.

3. The rotational speed of rotors and driving speed of a combine harvester were a significant parameter which influenced the losses of rapeseed on screens. The average rotational speed of rotors was approx. $580 \mathrm{~min}^{-1}$. The optimal driving speed was controlled directly by an operator but it was corrected by Intelli Cruise system, which automatically decreased or raised the driving speed of a machine in relation to the density of the mown field. The maximum mowing speed was $11 \mathrm{~km} \cdot \mathrm{h}^{-1}$.

4. The rotational speed of rotors, mowing speed and rotational speed of the combine engine have a significant effect on losses on screens at the rapeseed harvesting with the investigated New Holland CR 9080 combine, which was described with the multiple regression model.

\section{References}

Anil, J., Guruswamy, T., Desai, S., Basavaraj, T., Joshi, A. (1998). Effects of cylinder speed and feed rate on the performance of thrasher. Journal of Agriculture Science, 4, 1120-1123.

Baruah, D.C., Panesar, B.S. (2005a). Energy requirement model for a combine harvester - Part I: Development of component models. Biosystems Engineering, 90(1), 9-25.

Baruah, D.C., Panesar, B.S. (2005b). Energy requirement model for a combine harvester - Part II: Development of component models. Biosystems Engineering, 90(2), 161-171.

Beck, F., (2000). Die Reinigungsanlage im Mahderscher. Landtechnik Vol. 55, No. 2, 76-80.

Bieniek, J. (2003). Proces separacji ziarna zbóż na sicie daszkowym w zmiennych warunkach pracy. Wydawnictwo AR we Wrocławiu Rozprawy CXCVII, ISBN 0867-7964.

Bieniek, J. (2010). Separacja ziarna w kombajnach zbożowych. Wydawnictwo UP we Wrocławiu. Monografia XCVI, ISBN 978-83-60574-99-7.

Bieniek, J. (2011). Kombajnowy zbiór zbóż. AgEngPol, http://cuban.vipserv.org/agengpol/ Kombajnowy_zbior_zboz.pdf.

Dreszer, A. K., Pawłowski, T., Szczepaniak, J., Szymanek, M., Tanaś, W. (2008). Maszyny rolnicze. PIMR, Poznań, ISBN 978-83-921598-9-6. 
Górniak, J., Wachnicki, J. (2004). Pierwsze kroki w analizie danych - SPPS for Windows. Wyd. SPSS Polska, Kraków, ISBN 9788391287101.

Karpiński, Z., (2015). Rocznik statystyczny rolnictwa. Zakład wydawnictw statystycznych, Warszawa, ISBN 2080-8798.

Komarnicki, P., Bieniek, J., Banasiak, J. (2007). Operational effectiveness of a sieve-aerodynamic separator under the conditions of the variable load of sieves. Eksploatacja i Niezawodność - Maintenance and Reliability 4, 33-35.

Liu, C., Leonard, J., (1993). Monitoring actual grain loss from an axial flow combine in real time. Computers and Electronics in Agriculture, 9, 231-242.

Maertens, K., De Baerdemaeker, J., Ramon, H., De Keyser, R. (2001). An analytical grain flow model for a combine harvester. Part II: Analysis and application of the model. Journal of Agricultural Engineering Research, 79(2), 187-193. Doi: 10.1006/ jaer.2000.0681.

Miłosz, T. (2000). Zespoty młócaco-wydzielajace i czyszczace $w$ kombajnach do zbioru zbóż. IMBER, Warszawa, ISBN 83-86264-67-5.

Miu, P.I., Kutzbachb, H.D. (2008a). Modeling and simulation of grain threshing and separation in threshing units. Part I. Computers and Electronics in Agriculture 60, 96-104.

Miu, P.I., Kutzbachb, H.D. (2008b). Modeling and simulation of grain threshing and separation in axial threshing units. Part II. Application to tangential feeding. Computers and Electronics in Agriculture 60, 105-109.

Molendowski, F., Romański, L., Górnik, Ł. (2012). Ocena eksploatacyjna wybranych kombajnów do zbioru zbóż metodą wskaźnika zespolonego. Inżynieria Rolnicza, 4(139), Polskie Towarzystwo Inżynierii Rolniczej, 277-284.

Molendowski, F., Romański, L., Hutnik, K. (2011). Ocena porównawcza kombajnu zbożowego New Holland CS6070 z kombajnem Bizon rekord Z-058. Inżynieria Rolnicza, 8(133), Polskie Towarzystwo Inżynierii Rolniczej, 223-228.

Nik, M.A.E., Khademolhosseini, N., Abbaspour-Fard, M.H., Mahdinia, A., Alami-Saied, K. (2009). Optimum utilisation of low-capacity combine harvesters in high-yielding wheat farms using multi-criteria decision making. Biosystems Engineering, 103(3), 382-388. Doi: 10.1016/j .biosystemseng.2009.04.009.

Przybył, J., Sęk, T. (2010). Zbiór zbóż i roślin podobnych technologicznie. Wydawnictwo Uniwersytetu Przyrodniczego w Poznaniu, ISBN 978-83-7160-624-3.

Rolniczy Przegląd Techniczny, (2012). Kombajny zbożowe. Wydanie specjalne, Wyd. APRA, ISBN 978-83-928939-3-6.

Tanaś, W., Dreszer, K. A., Zagajski, P., (2008). Wpływ wilgotności na straty i uszkodzenia ziarna podczas zbioru kombajnowego zbóż. Inżynieria Rolnicza, 9(107), 299-303.

Tanaś, W., Zagajski, P. (2010). Wpływ automatycznej regulacji zespołów roboczych na jakość pracy kombajnów zbożowych. Inżynieria Rolnicza, 4(122), Polskie Towarzystwo Inżynierii Rolniczej, 245-251.

Wecker, P., Kutzbach, H., Reitz P. (1996). Developments in European Combine Harvesters. Agricultural Engineering, 96, Madryt, Paper 96-069.

Żak, W., Zagajski, P., Dreszer, A. K. (2007). Zespoły żniwne do zbioru rzepaku. Journal of Research and Applications in Agricultural Engineering, Vol. 52, 1, 62-67.

www1 - http://www.raportrolny.pl/kombajny/item/64-new-holland-cr9090-elevation-kombajn-onajwi\%C4\%99kszej-wydajno\%C5\%9Bci-na-\%C5\%9Bwiecie.

www2 - http://www.metaltech.com.pl/pl/Katalog/Przyczepy/Wozy-przeladowcze-typ-PP/PP20.html. www3 - www.NewHollandIndustrial.com. 
Evaluation of New Holland...

\section{OCENA PRACY KOMBAJNU ZBOŻOWEGO NEW HOLLAND CR9080}

Streszczenie. W artykule przedstawiono ocenę eksploatacyjną pracy zespołu czyszczącego kombajnu zbożowego NH CR9080. W obecnie stosowanych maszynach do zbioru zbóż nastąpił istotny postęp techniczny i technologiczny, między innymi wzrosła wydajność, a w wyposażeniu pojawiły się elementy poprawiające ich jakość pracy. Celem badań było określenie jakości pracy zespołu czyszczącego kombajnu zbożowego firmy New Holland CR9080. Podczas badań wyznaczono straty na sitach i na rotorach, wysokość cięcia rzepaku, prędkość koszenia, obroty wentylatora, rotorów i silnika. Zależność strat na sitach od parametrów pracy kombajnu wyznaczono modelem regresji wielorakiej. Istotny wpływ na straty na sitach przy zbiorze rzepaku badanym kombajnem mają: prędkość obrotowa rotorów, prędkość koszenia oraz prędkość obrotowa silnika kombajnu.

Słowa kluczowe: kombajn zbożowy, zespół czyszczący, zbiór, straty rzepaku 
